Foss. Rec., 24, 9-18, 2021

https://doi.org/10.5194/fr-24-9-2021

(C) Author(s) 2021. This work is distributed under

the Creative Commons Attribution 4.0 License.

\title{
A new late Miocene bovid (Mammalia: Artiodactyla: Bovidae) from Çorakyerler (Turkey)
}

\author{
Dimitris S. Kostopoulos ${ }^{1}$, Ayla Sevim Erol ${ }^{2}$, Alper Yener Yavuz ${ }^{3}$, and Serdar Mayda 4 \\ ${ }^{1}$ School of Geology, Aristotle University of Thessaloniki, 54124 Thessaloniki, Greece \\ ${ }^{2}$ Faculty of Languages, History and Geography, Department of Anthropology, Ankara University, Ankara, Turkey \\ ${ }^{3}$ Faculty of Art and Sciences, Department of Anthropology, Mehmet Akif Ersoy University, Burdur, Turkey \\ ${ }^{4}$ Faculty of Science, Department of Biology, Ege University, Izmir, Turkey
}

Correspondence: Dimitris S. Kostopoulos (dkostop@geo.auth.gr)

Received: 24 November 2020 - Accepted: 21 December 2020 - Published: 3 February 2021

\begin{abstract}
We describe here five new bovid crania from the Çorakyerler fossil site (Tüglu Formation, Çankırı Basin, north-central Anatolia, Turkey), the fauna of which is dated by magneto- and biostratigraphy to the late Miocene, around the Vallesian-Turolian boundary. The material is assigned to a new bovid taxon of medium-to-large size, Gangraia anatolica gen. and sp. nov., characterized by horn cores that are long, keelless, compressed, obliquely inserted on the frontals, transversally ridged, moderately diverging from each other, slightly twisted homonymously, and sigmoidally curved in lateral view with long, fairly straight tips. The horn core features, along with the presence of a single large sinus occupying the pedicle and the base of the horn core, a strong cranial flexion, a short braincase, the presence of a distinct dorsal parietal boss, wide-apart temporal crests, and a widened anteriorly basioccipital, indicate a mixture of caprine-like and alcelaphine-like features that relate Gangraia anatolica gen. and sp. nov. to the Alcelaphini-CapriniHippotragini clade.
\end{abstract}

\section{Introduction}

The Çorakyerler fossil site $\left(40^{\circ} 36^{\prime} 32^{\prime \prime} \mathrm{N}, 33^{\circ} 38^{\prime} 01^{\prime \prime} \mathrm{E}\right.$; altitude $747 \mathrm{~m}$ ) is located in the fluvial floodplain deposits of the Tüglu Formation in the Çankırı Basin of north-central Anatolia (Turkey) (Sickenberg, 1975; Kaymakçi et al., 2001). The locality was discovered in the early 1970s but became known worldwide after the 2000s due to its hominoid findings (e.g. Sevim Erol et al., 2001, 2020; Begun et al., 2003; Güleç et al., 2007). Systematic excavations from 2001 onwards led by one of us (Ayla Sevim Erol) allowed us to considerably increase the identifiable fossil mammal remains that now reach nearly 4000 specimens, representing mostly hipparionine horses, bovids, giraffids, rhinos, and carnivores (Sevim Erol et al., 2020). Published biochronological and magnetostratigraphic data (e.g. Köhler, 1987; Ünay et al., 2006; Güleç et al., 2007; Geraads, 2013; Kaya et al., 2016) suggest an early Turolian age for the Çorakyerler fauna, though an older (latest Vallesian) age is not yet dismissed (e.g. Kostopoulos et al., 2020).

Köhler (1987) studied a limited bovid sample collected by Sickenberg's team, whereas Geraads (2013) provided a brief description of the bovid material collected around 2000 (collection numbers up to ÇO 450). More recently, Kostopoulos et al. (2020) added to the faunal list of the site the new bovid species Qurliqnoria chorakensis Kostopoulos, Sevim Erol, Mayda, Yavus, and Tarhan, 2020, based on material collected between 2001 and 2018. Within the frame of the same study undertaken in summer 2019 in the Faculty of Languages, History, and Geography of Ankara University, a medium/large-sized bovid with unusual horn core and cranial appearance has been revealed. In this study, we describe this new taxon and discuss its possible phylogenetic relationships within Bovidae.

\section{Material and methods}

The studied material includes five partial crania preserving horn cores and forms part of the Çankırı Museum collection (Turkey), registered under the locality prefix ÇO. A set of palates and several upper and lower tooth rows are likely affiliated with the same taxon. Nevertheless, as no cranium pre- 
serving the dentition is so far known and as there are several bovid taxa of comparable size in the locality, we refrain at the moment from directly associating dental features to the new taxon concept and will wait for more complete material.

Standard cranial terminology has been used for descriptions (e.g. Gentry, 1971, 1992; Kostopoulos, 2009). Horn cores are characterized as homonymously twisted when the right horn core follows a clockwise torsion and heteronymously twisted otherwise. The back angle between the longest basal diameter of the horn core compared to the sagittal plane is termed here the "oblique angle" (sensu Wang et al., 2018). The compression index expresses the minimum basal against the maximum basal diameter of the horn core base (\%). All linear measurements are in millimetres; angles are in degrees $\left({ }^{\circ}\right)$.

Extant tribal bovid phylogeny follows Bibi (2013), and the more recent analysis by Chen et al. (2019) resulted from whole-genome sequences.

\subsection{Nomenclatural acts}

This published work and the nomenclatural acts it contains have been registered in ZooBank: (http://www.zoobank.org/, date of registry: 28 December 2020) with the following LSID (reference): http://zoobank.org/NomenclaturalActs/ DF92F731-BE16-43C6-9E7B-CCC05F4F1A26 and http://zoobank.org/NomenclaturalActs/727045D3-62414172-88A4-AE8AA1FA6EF4. The electronic edition of this work has been archived and is available from the following digital repositories: Deutsche Nationalbibliothek, US Library of Congress, Portico, and CLOCKSS.

\subsection{Abbreviations}

APD - anteroposterior diameter; TD - transverse diameter; $H$ - height; $L$ - length; max - maximum; min - minimum; ACH clade - Alcelaphini-Caprini-Hippotragini clade.

\section{Systematic palaeontology}

Order Artiodactyla Owen, 1848

Family Bovidae Gray, 1821

Subfamily Antilopinae Gray, 1821

(sensu Kingdon, 1982)

Tribe indeterminate

Genus Gangraia nov.

Type and only species

Gangraia anatolica sp. nov.; see below.

\section{Etymology}

From " $Г \alpha \gamma \gamma \rho \alpha$ " (= Gangra or Changra), the ancient Greek name of the Çankırı area.

\section{Diagnosis}

A medium- to large-sized bovid with long, keelless, compressed and transversally ridged horn cores slightly twisted homonymously, inserted widely apart and slightly behind the orbits; sigmoidal horn core curvature in lateral view with variably long straight tips; great basal horn core axis strongly angled compared to the sagittal plane. Braincase short with a distinct dorsal parietal boss; wide-apart temporal crests; strong craniofacial flexion; extensively pneumatized frontals with a single large sinus occupying the pedicle and the base of the horn core; quadrangular shaped and grooved basioccipital with very strong posterior and anterior tuberosities; females horned.

\section{Gangraia anatolica sp. nov.}

(Figs. 1-3)

\section{Etymology}

From the geographic area of Anatolia that makes up most of modern Turkey.

\section{Holotype}

ÇO 3187, partial cranium with braincase and both horn cores.

\section{Paratypes}

ÇO 3476, partial cranium with braincase and both horn cores; ÇO 3124, partial cranium with braincase and both horn cores; ÇO 683, part of cranium with complete right and basal part of the left horn core; ÇO 1427, frontlet.

\section{Type locality}

Çorakyerler fossil site near Çankırı, Turkey.

\section{Type horizon}

Tüglu Formation (Upper Miocene) in Çankırı Basin, Turkey.

Age

Late Miocene. Geraads (2013) suggests an early Turolian age for the Çorakyerler fauna. Magnetostratigraphic correlation by Kaya et al. (2016) frames the fauna between 8.11 and 7.64 Ma. Kostopoulos et al. (2020) suggest an age around the Vallesian-Turolian boundary $(\sim 8.7 \mathrm{Ma})$.

\section{Host institution}

Çankırı Museum, Turkey. 


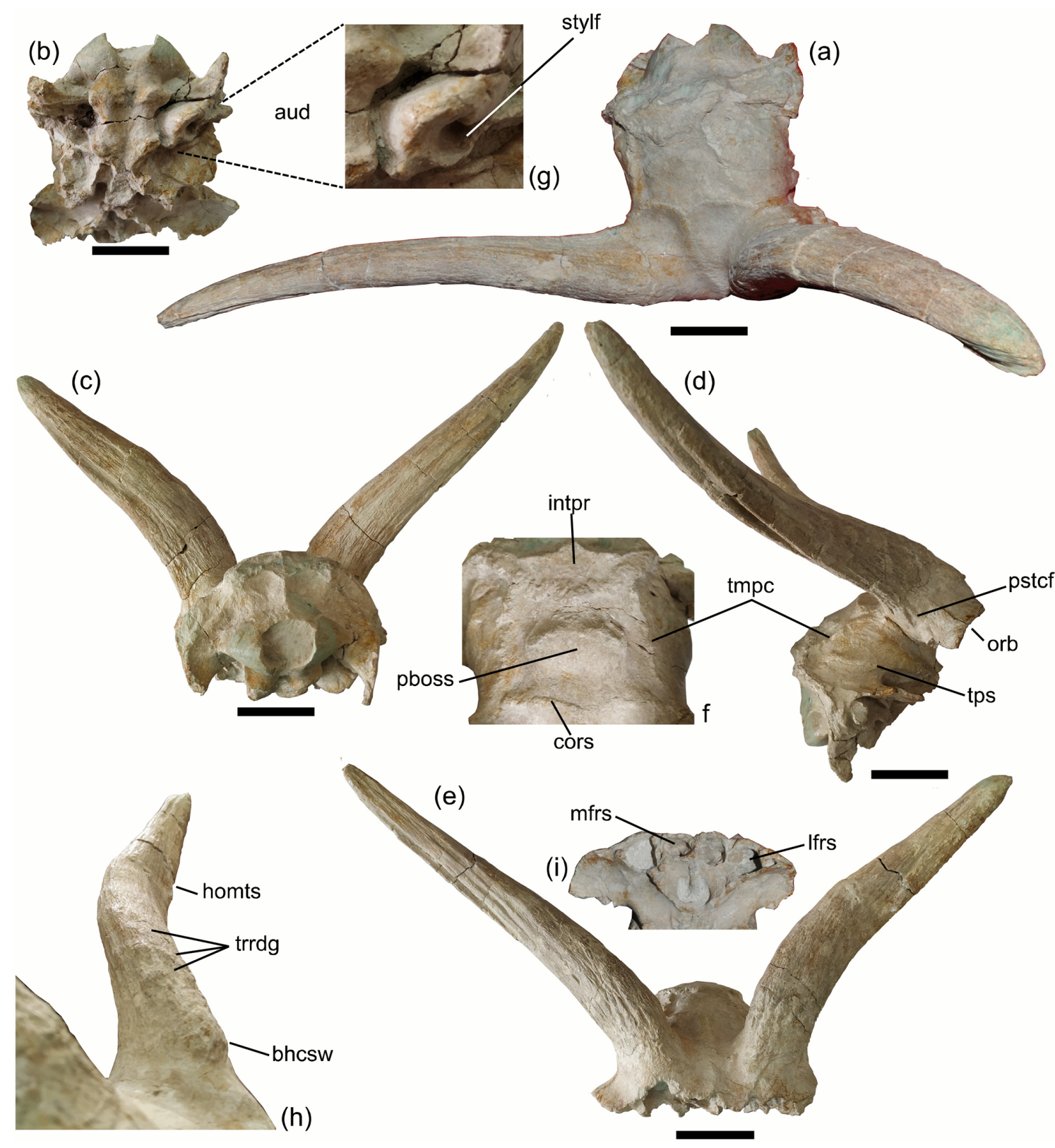

Figure 1. Gangraia anatolica gen. and sp. nov. from Çorakyerler, Turkey. Holotype cranium ÇO 3187 in (a) dorsal, (b) ventral, (c) caudal, (d) right lateral, and (e) frontal views. (f) Detail of the dorsal parietal surface; (g) close up of auditory bulla; (h) antero-medial view of the left horn core; and (i) ventral view of the frontals. (a)-(e) Scale bar: $5 \mathrm{~cm}$; (f)-(i) not to scale. Abbreviations: stylf: stylohyal fossa; aub: auditory bulla; intpr: interparietal; pboss: parietal boss; tmpc: temporal crest; tps: temporo-parietal suture; cors: coronal suture; pstcf: postcornual fossa; orb: orbit; mfrs: median frontal sinus; lfrs: lateral frontal sinus; homts: homonymous torsion; trrdg: transverse ridges; and bhcsw: basal horn core swelling.

\section{Diagnosis}

Same as for the genus.

\section{Description}

Both ÇO 3187 (Fig. 1) and ÇO 3476 (Fig. 2a) appear barely affected by taphonomic deformation, which is rather com- mon on the site; hence, the description is based mainly on these two crania. ÇO 3124 (Fig. 3) is somehow rostrocaudally compressed; as a result, braincase shortening is exaggerated. In some cases (i.e. Table 1), one of the two horn cores of the same individual appear more rostrocaudally compressed than the other, especially at its proximal part; we suspect that this is also due to postmortem compression, 


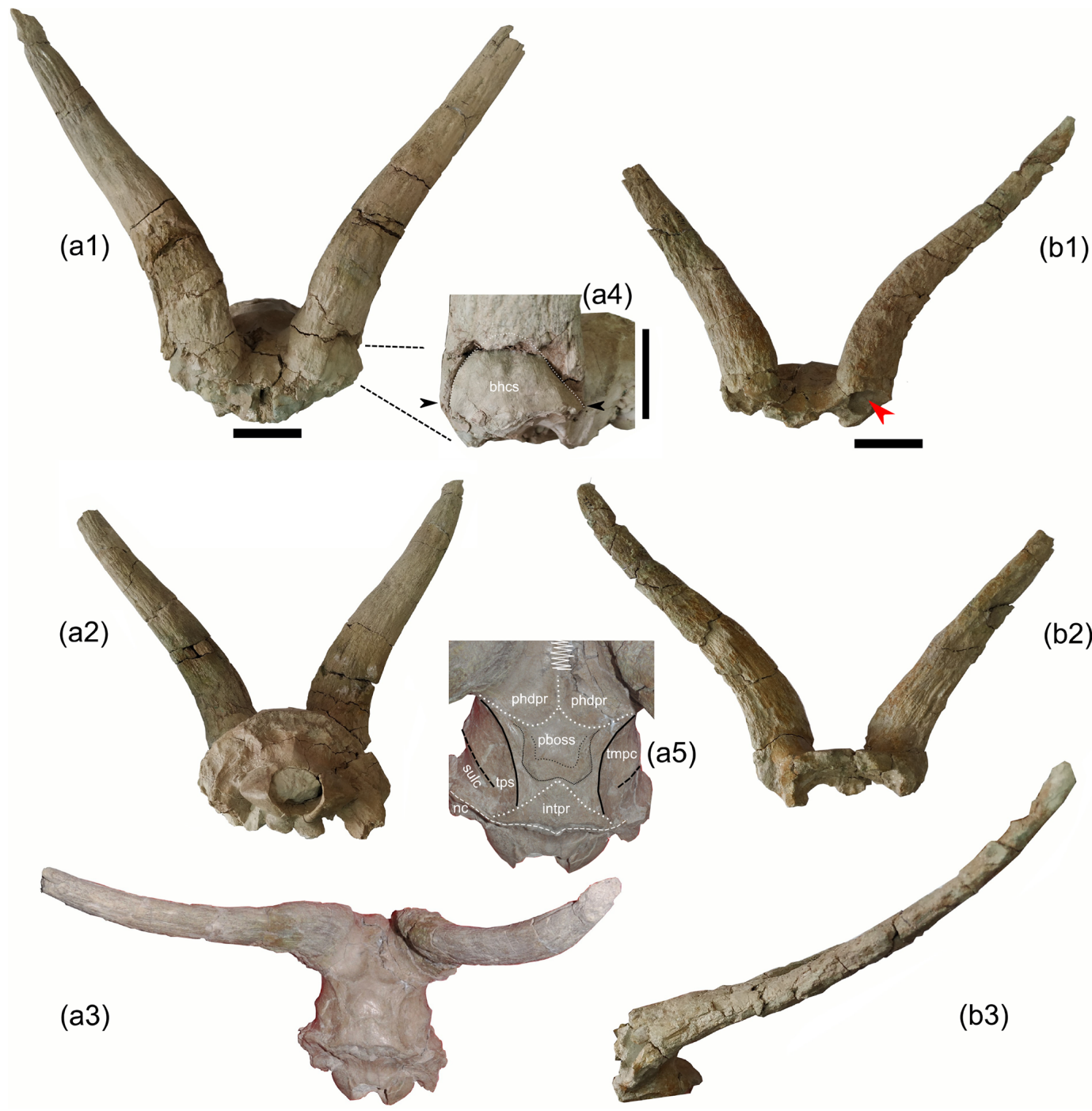

Figure 2. Gangraia anatolica gen. and sp. nov., from Çorakyerler, Turkey. Paratype cranium ÇO 3476 (a) and female frontlet ÇO 1427 (b); (1) frontal views; (2) caudal views; (a3) dorsal view; (a4) close up of the base of the left horn core in lateral view showing the single sinus occupying the pedicle and the basal horn core (arrows indicate the pedicle-horn core contact); (a5) close up of the dorsal parietal surface with marked anatomical details; and (b3) lateral view. The arrow in (b1) indicates the frontal sinus occupying the pedicle. Abbreviations: bhcs: basal horn core sinus; phdpr: post horn core depression; pboss: parietal boss; tmpc: temporal crest; tps: temporo-parietal suture; nc: nuchal crest; intpr: interparietal; and sulc: sulcus. (a1)-(a3) and (b1)-(b3) scale bar: $5 \mathrm{~cm}$; (a4) and (a5) not to scale.

and we suggest considering the less compressed dimensions as the most reliable.

ÇO 3187, ÇO 3476, ÇO 3124, and ÇO 683 form a very homogeneous sample in terms of their morphology, absolute dimensions, and proportions (Table 1; Figs. 1-3). On the other hand, the frontlet ÇO 1427 (Fig. 2b) has significantly (20\%) slimmer horn cores and consequently a less broad cranium at the lateral horn core level $(\sim 9 \%)$, though the braincase width just behind the horn cores is not much narrower (Table 1). The morphological features of the frontal area in ÇO 1427 are also very similar to those of the holotype, but the interfrontal suture is not pinched but smoothly convex and less complicated. The great length of the horn cores prevents the possibility of a young male individual; we interpret therefore the observed differences between ÇO 1427 and the rest of the crania as representing sexual dimorphism.

The braincase is short and wide (Figs. 1a, 2a.3, 3a) with a length to width ratio (length: from the junction of coronalinterfrontal sutures to inion; width: maximum braincase width) between $59 \%$ and $62 \%(n=2)$. Placing in a horizontal position the glenoid articular surface, the basioccipital forms an angle of about $70^{\circ}$ with the horizontal plane, inferring a strongly angled braincase compared to the face (Figs. 1d, 3c). The dorsal braincase plane forms an angle of $115^{\circ}$ (in ÇO 3187) to $125^{\circ}$ (in ÇO 3476) with the occipital plane. The temporal crests are weak but visible (Figs. 1a, f, 


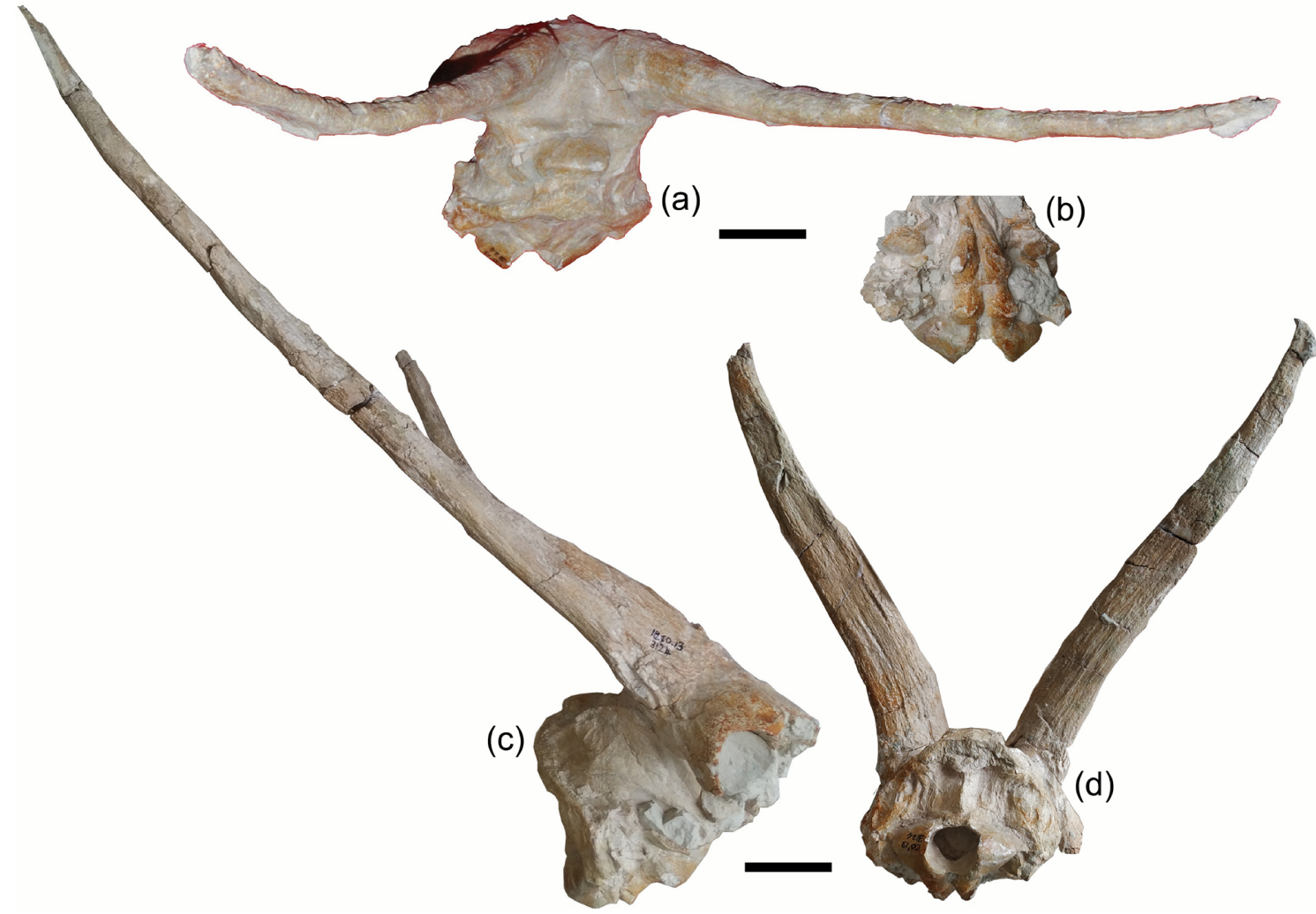

Figure 3. Gangraia anatolica gen. and sp. nov., from Çorakyerler, Turkey. Paratype cranium ÇO 3124 in (a) dorsal, (b) ventral, (c) right lateral, and (d) caudal view. Scale bar: $5 \mathrm{~cm}$.

2a.3, a.5); they are wide-apart and run parallel to each other on the dorsal surface of the braincase till the interparietal which is transversally elongated and rather narrow (Figs. 1f, 2a.5). A distinct large parietal boss occurs behind the coronal suture (ÇO 3124, 3476; Figs. 1f, 2a.3, a.5, 3a).

The occipital condyles with the occipital plane form a $\sim 100^{\circ}$ angle (upper) and are directed caudally. The occipital faces dorso-caudally and has a semi-circular contour defined dorsally by a moderate to strong nuchal crest (Figs. 1c, 2a.2, 3d). The occipital protuberance is weak to moderate, and the mid-occipital crest is slight pinched, surrounded by two well-defined ligament depressions (less deep in ÇO 3187 than in ÇO 3476, in which the occipital relief is much more intense and the occiput projects caudally compared to the main occipital level; Figs. 1c, 2a.2). The paroccipital processes are compressed, broad at their bases $(22.5 \mathrm{~mm}$ in ÇO 3187 and $29.3 \mathrm{~mm}$ in ÇO 3476), fast tapering and curving caudo-ventrally, and overpassing the ventral condyle level. The auditory bulla ( $L: 36 \mathrm{~mm}$; TD: $21.4 \mathrm{~mm}$; ÇO 3187 ) is long, narrow, and slightly curved rostrocaudally, associated with a large stylohyal fossa (Fig. 1g). The basioccipital is weakly angled on the basisphenoid ( $\sim 160^{\circ}$; ÇO 3476). It is short, quadrangular to square in shape, and grooved with very strong anterior tuberosities, the latter extending significantly rostrally (Figs. 1b, 3b). The foramen oval is moder- ately large $(12 \mathrm{~mm} \times 6 \mathrm{~mm}$ in ÇO 3187), opens at the level of the anterior tuberosities of the basioccipital, and faces mostly ventrally. The mastoids are relatively small and face mostly laterally (Fig. 1d). The temporo-parietal suture is directed obliquely upwards till the interparietal, and it is raised, defining with the nuchal crest a markedly depressed area (sulcus) at the latero-caudal part of the braincase for the temporal musculature (ÇO 3187, 3124, 3474; Figs. 1d, 2a.5).

The orbital rims protrude significantly laterally (Fig. 1e). The orbits are rather small compared to the cranium size (APD: $35 \mathrm{~mm}$ in ÇO 3124) and rounded (Fig. 3c). The frontals are significantly angled in sagittal profile (110$\left.130^{\circ}\right)$. The frontal area between the orbits is extensively pneumatized: in each half, a medial sinus (TD: $16.8 \mathrm{~mm}$; $H: 14.5 \mathrm{~mm}$ ) is associated with a larger lateral one (TD: $19.0 \mathrm{~mm} ; H: 25.8 \mathrm{~mm}$ ) (Fig. 1i). This lateral sinus is separated by a thin septum from a single large sinus occupying the rest of the pedicle and the base of the horn core, as is clearly seen in ÇO 3476 and ÇO 1427 (Fig. 2a.4, b.1). The interfrontal suture is tightly zigzag in shape (simpler in ÇO 1427); it is slightly raised at the caudal part and in front of the horn cores and appears much more pinched in the specimen ÇO 3476 (Figs. 1e, 2a.5) than in the rest of the examined crania. The fronto-parietal (coronal) suture passes directly behind the pedicles, and it is slightly curved with a 
Table 1. Gangraia anatolica gen. and sp. nov., from Çorakyerler, Turkey: measurements of holotype (ÇO 3187) and paratype crania (in millimetres except if marked otherwise).

\begin{tabular}{|c|c|c|c|c|}
\hline & ÇO 3187 & ÇO 3124 & ÇO 3476 & ÇO 1427 \\
\hline Width of the skull at the posterolateral edges of the horn cores & 136.3 & 129 & 138 & 122.8 \\
\hline Width of the skull just behind the horn cores & 89.2 & 95.3 & 89.7 & 89.6 \\
\hline Bi-orbital width & $(158)$ & 158.0 & & \\
\hline Maximum width of the braincase & 98.8 & $(89)$ & 97.3 & \\
\hline Bi-mastoid width & 117.0 & 117.0 & 129.5 & \\
\hline Bi-condylar width & 80.0 & 70.6 & 71.2 & \\
\hline Width at the posterior tuberosities of the basioccipital & 42.6 & 34.0 & 37.0 & \\
\hline Width at the anterior tuberosities of the basioccipital & 35.6 & 30.0 & $(32)$ & \\
\hline Width of foramen magnum & 26.0 & 27.1 & 29.0 & \\
\hline Length from bregma to inion & 58.7 & & 60.7 & \\
\hline Height of occiput & 48.2 & $(57.8)$ & 49.5 & \\
\hline Height from basion to inion & 66.0 & 78.3 & 78.0 & \\
\hline Maximum diameter of auditory bulla & 36.0 & & & \\
\hline Angle of horn core insertion (compared to cranial roof) & $75^{\circ}$ & & $80^{\circ}$ & \\
\hline
\end{tabular}

medial indentation toward the frontals (Figs. 1f, 2a.5); the two frontal subsectors defined by the coronal and the interfrontal suture appear weakly (ÇO 3187, ÇO 683) to strongly (ÇO 3476) depressed (Fig. 2a.5). The supraorbital foramina are very small, not sunken into pits, and widely apart from each other $(\sim 59 \mathrm{~mm})$. They extend rostrally on the frontals by weak furrows. A large $(H: 28 \mathrm{~mm}$; TD: $10 \mathrm{~mm}$ in ÇO 3476) but very shallow postcornual groove is located below the horn core base (detected also on the right side of ÇO 3124 and ÇO 683; in most other specimens, it is barely or not recognized due to post-burial alterations) (Fig. 1d).

The pedicles are short with sloping sides. Their major basal axis (as that of the horn cores) forms a strong oblique angle compared to the sagittal plane $\left(40-60^{\circ}\right)$. The horn cores are inserted widely apart above the orbits forming a $75-80^{\circ}$ angle with the dorsal braincase plane (Figs. 1a, c$\mathrm{d}, 2 \mathrm{a} .1-2, \mathrm{~b} .3,3 \mathrm{a}, \mathrm{c})$. They are moderately long to long (Fig. 3c) compared to the cranium size; their length along the anterior surface ranges from $275-280 \mathrm{~mm}$ (ÇO 1427, ÇO 3187 , ÇO 3476) to $420 \mathrm{~mm}$ (ÇO 3124). They are keelless and slightly twisted homonymously. In frontal view, they appear openly lyrated with an internal distance at the apexes reaching $400 \mathrm{~mm}$ (ÇO 3187, ÇO 3124) and the divergence angle ranging from 55 to $80^{\circ}$. In lateral view, they delineate a very open "S"; their anterior edge is convex at the proximal fifth, then gently concave, leading to straight up or slightly forward re-curved tips (Figs. 1d, h, 2a.1, b.1, 3c). They are moderately to strongly compressed rostrocaudally (mean compression index $58 \%$ ) with an oval to elliptical cross section throughout their length, flattened posterior, and slightly more convex anterior surface. In ÇO 3187, CO 3476, and ÇO 683, the horn cores taper rather fast upwards but more regularly on ÇO 3124 and ÇO 1427. The horn core surface shows clear developmental transverse ridges all along its length (Figs. 1h, 2a). Thin irregular longitudinal furrows run along the horn core surface, but more deep and distinct grooves can also be seen, especially in the basal part at the middle of the anterior surface (one to two grooves vanished from the upper and lower third) and at the posterior surface (one main deep groove vanishing towards the two extremes) (Figs. 1c, e, 3d). Cranial and horn core dimensions are given in Tables 1 and 2.

\section{Comparison and discussion}

The particular cranial and horn core features of the Çorakyerler bovid find - to our knowledge - no match within the otherwise extremely rich late Miocene Eurasian bovid record. The strongly angled braincase on the face, the short basioccipital with enlarged anterior tuberosities and the overall horn core shape and morphology easily remove the Çorakyerler taxon from the group of late Miocene Eurasian boselaphine-like bovids (i.e. Tragoportacini; sensu Bibi et al., 2009). The basicranial morphology, the relief of dorsal and lateral braincase surface, and the insertion, orientation, and morphology of the horn cores of the Çorakyerler bovid are distinctly different than similar-sized "protoryxoid" bovids (Gentry, 1971; Kostopoulos, 2009), such as Protoryx Major, 1891, Palaeoryx Gaudry, 1861, Procobus Khomenko, 1913, Skoufotragus Kostopoulos, 2009, Macrotragus Chen and Zhang, 2007, and Huabeitragus Chen and Zhang, 2007, and additionally larger than Tragoreas Schlosser, 1904, Sporadotragus Kretzoi, 1968, and Olonbulukia Bohlin, 1937, and all of them are characterized by untwisted and variably medio-laterally compressed horn cores with small oblique angles and no transverse ridges. Qurliqnoria Bohlin, 1937, known also from Çorakyerler (Kostopoulos et al., 2020), differs from the studied taxon in its smaller size and heteronymously twisted horn cores curving caudo-laterally. 
Table 2. Gangraia anatolica gen. and sp. nov., from Çorakyerler, Turkey: measurements of horn cores (in millimetres except if marked otherwise). Abbreviations: max.: maximum; min.: minimum.

\begin{tabular}{|c|c|c|c|c|c|c|c|c|c|c|}
\hline & \multicolumn{2}{|c|}{ ÇO 3187} & \multicolumn{2}{|c|}{ ÇO 3124} & \multicolumn{2}{|c|}{ ÇO 3476} & \multicolumn{2}{|c|}{ ÇO 683} & \multicolumn{2}{|c|}{ ÇO 1427} \\
\hline $\begin{array}{l}\text { Internal basal distance between the horn cores } \\
\text { Internal horn core distance at the tips } \\
\text { Horn core length (curved, anterior) } \\
\text { Horn core length (straight, anterior) }\end{array}$ & 47.5 & & \multicolumn{2}{|c|}{$\begin{array}{c}31.6 \\
400\end{array}$} & \multicolumn{2}{|c|}{$\begin{array}{c}32.6 \\
>330\end{array}$} & & & $\begin{array}{r}39 \\
> \\
2 \\
2\end{array}$ & \\
\hline & Right & Left & Right & Left & Right & Left & Right & Left & Right & Left \\
\hline Max. & 54.0 & 51.0 & 53.0 & 61.0 & 68.8 & 59.9 & 57.2 & 52.6 & 43.8 & 48.3 \\
\hline Min. basal diameter & 30.0 & 32.6 & 40.3 & 30.0 & 38.5 & & 40.9 & & 25.7 & 27.7 \\
\hline Max. diameter at $10 \mathrm{~cm}$ above base & 32.2 & 43.0 & 38.0 & 46.2 & 47.6 & 39.8 & 40.0 & 35.7 & 32.2 & 33.2 \\
\hline $\begin{array}{l}\text { Min. diameter at } 10 \mathrm{~cm} \text { above base } \\
\text { Oblique angle }\end{array}$ & 26.9 & $\begin{array}{r}23.5 \\
40^{\circ}\end{array}$ & 22.5 & 20.0 & $\begin{array}{r}26.3 \\
65^{\circ}\end{array}$ & 28.8 & 25.4 & 27.6 & 16.3 & $\begin{array}{r}17.2 \\
55^{\circ}\end{array}$ \\
\hline
\end{tabular}

The braincase, basicranial, and horn core features of the Çorakyerler taxon are also very different from those of late Miocene ovibovine-like bovids, such as Hezhengia Qiu, Wang, and Xie, 2000, Shaanxispira Liu, Li, and Zhai, 1978, Urmiatherium Rodler, 1888, Plesiaddax Schlosser, 1903, Tsaidamotherium Bohlin, 1935, Mesembriacerus Bouvrain, 1975, and Criotherium Major, 1891 (to mention only the similar-sized ones). Unlike the Çorakyerler taxon, most of those taxa show a shortened parietal that tends to be on the same plane with the occipital (apart from Shaanxispira and Mesembriacerus), the thickened basioccipital is trapezoid shaped or barrel-like with weak anterior tuberosities and additional stop facets for atlas, the frontals are much more raised, and the horn cores are either significantly shorter and much more robust at the base merging with each other medially or anteromedially (i.e. in Hezhengia, Urmiatherium, Tsaidamotherium, and Plesiaddax) or strongly torsioned and keeled (i.e. in Shaanxispira Criotherium) and sometimes strongly bent and/or curved posterolaterally or laterally (i.e. in Mesembriacerus, Hezhengia, and Plesiaddax) (e.g. Bouvrain, 1975; Köhler, 1987; Geraads and Spassov, 2008; Shi, 2014; Shi et al., 2014, 2016; Kostopoulos, 2014).

Hence, the unique combination of morphometric features characterizing the described late Miocene bovid taxon from Çorakyerler, allows us to recognize it as a new genus and species, Gangraia anatolica. The most striking features of Gangraia anatolica are the very long, slender, homonymously twisted, and transversally ridged horn cores of changing orientation through ontogeny, the hollowed pedicle and horn core base occupied by a single large sinus, the presence of a distinct boss on the dorsal parietal surface of the cranium, the laterally protruding orbital rims, and the short and rostrally widened basioccipital. This combination of characteristics removes Gangraia anatolica gen. and sp. nov. quite easily from Bovinae Gray, 1821, but none of them is exclusive to any extant tribe of Antilopinae Gray, 1821, or any extinct taxon above the genus level recognized within them.
Very long and slender horn cores similar to those of Gangraia may commonly be found in members of Aepycerotini, Reduncini, Alcelaphini, Hippotragini, and Pantolops + Caprini clades (Pilgrim, 1939; Gentry, 1979, 1990, 1992, 2000, 2010; Vrba, 1979, 1997; Geraads et al., 2008). In a different way, however, from Gangraia, aepycerotine horn cores show a heteronymous twist (e.g. Gentry, 1992, 2010; Harris, 2003; Geraads, 2019), whereas those of chiru and most caprines are usually keeled (e.g. Gentry, 1992, 2000). Homonymously twisted horn cores are occasionally present among Alcelaphini and quite commonly within Caprini, as well as in some Miocene taxa allied to this tribe (e.g. Gentry, 2000; Kostopoulos, 2014). Transverse developmental ridges on the horn cores appear as a rule in Reduncini, Alcelaphini, and Aepycerotini (Gentry, 1979, 1992; Vrba et al., 1994; Vrba, 1997; Bibi et al., 2017) and very randomly outside of these tribes (e.g. in springbok and dibatag among Antilopini). A weakly concave (anteriorly) horn core in lateral view is a rather primitive feature retained or regained secondarily in several crown bovid taxa usually of small size (e.g. in the four-horned antelope, Tetracerus among Bovinae, some Cephalophini, most Reduncini, several dwarf antelopes, dibatag, and grey rhebok) (e.g. Gentry, 1992, 2000). This character is rather rare in larger-sized taxa (in several alcelaphines and the chiru), and among Eurasian Miocene bovids with a size similar to Gangraia, it is recognized only in Procobus. As in several members of the Alcelaphina subtribe (Vrba, 1997), the horn cores of Gangraia become concave soon above the base, outlining a very open " $\mathrm{S}$ " of unequally distributed curvature along its length (i.e. a short convex stem, a long concave caching arch, and a fairly straight and long stabbing zone; based on Lundrigan, 1996).

The combination of wide-apart temporal lines, a noninflated auditory bulla, and the presence of a single large sinus occupying the pedicle and horn core base seen in Gangraia is quite unlike Aepycerotini, Antilopini, Cephalophini, and Reduncini, and it links it more closely to the ACH clade (Alcelaphini-Caprini-Hippotragini) (Gentry，1992，2010; 
Vrba et al., 1994; Vrba, 1997). Horn core pneumatization is much less in Gangraia than in extant Caprini but comparable to that of several late Miocene taxa allied to this tribe (e.g. Gentry, 2000). Additionally, the protruding orbital rims and shortened basioccipital with strong anterior tuberosities of Gangraia are more like to Caprini than other members of the ACH clade or Antilopinae in general. On the other hand, only the Damaliscina subtribe of Alcelaphini and some Hippotragini show a distinct and localized parietal boss within the ACH clade (Vrba, 1997; Dimitris S. Kostopoulos, personal observation, 2019).

\section{Conclusion}

The common phenomena of convergent evolution along with the short internal branches and the usually fragmentary nature of the fossil record challenge most morphology-based phylogenetic approaches to both extant and extinct taxa of Bovidae (e.g. Gentry, 1992; Bibi et al., 2009; Bibi and Vrba, 2010; Hassanin et al., 2012; Geraads, 2019; Chen et al., 2019). The here-described late Miocene bovid Gangraia anatolica gen. and sp. nov. from Çorakyerler, Turkey, is such an example. Cranial and horn core morphology of Gangraia anatolica suggests a mixture of characteristics that prevent the direct assignment to any crown bovid tribe. Moreover, lacking information (especially the absence of dentition associated with the Çorakyerler taxon) makes any further attempt at phylogenetic correlation through parsimony difficult at present. The available morphological data rather point to a scenario in which Gangraia is an offshoot near the origin of the Alcelaphini-Caprini-Hippotragini (ACH) clade, showing an amalgam of alcelaphine-like and caprine-like cranial and horn core features. In this respect, it may be used as an additional argument in favour of the opinion of Geraads (2019) on the presence of hidden fossil bovid tribes masked in modern classifications.

For the most part, the horn apparatus of Gangraia anatolica recalls rather an alcelaphine than a caprine or hippotragine (i.e. homonymous twist, presence of transverse ridges, changing horn orientation through ontogeny, and a single large sinus extending into the pedicle). As previous studies have, however, shown, the horn morphology is highly convergent and strongly correlated with fighting behaviour in bovids (e.g. Lundrigan, 1996, and references therein). Hence, a similar agonistic and life style would reasonably explain most of the parallelisms between Gangraia and the much younger (Pliocene to Pleistocene) and almost exclusively African Alcelaphini. Extant alcelaphines represent high-density and gregarious open-plain (savanna grassland/woodland) grazers exhibiting a complex fighting behaviour including ramming and wrestling associated with kneeling on the carpal join.

The well-developed catching arch and the estimated long reach of Gangraia horns also suggest wrestling as the pri- mary fighting behaviour (Lundrigan, 1996); transverse ridges may prevent horns from slipping between opponents and strengthen horns at maximum bedding stress conditions (Alvarez, 1990). The little sexual dimorphism observed among cranial specimens of Gangraia is again indicative of advanced gregariousness (Estes, 1974). It remains, therefore, to be seen in forthcoming studies if the presently unknown masticatory morphology of Gangraia also fulfils a pure grazer condition, as that of African alcelaphines.

Bovid biodiversity at the primate-bearing Çorakyerler site appears extremely high including 10 species at least: up to two boselaphine-like, four antilopine, and up to five caprine/ovibovine-like taxa have been recognized so far (Geraads, 2013; Kostopoulos et al., 2020; present work and Dimitris S. Kostopoulos, personal observation, 2019). Smallto medium-sized bovid taxa balance in number with larger ones (six species against five, respectively). Gazelles have a very low signal in contrast to spiral-horned antelopes, whereas "bizarre", specialized bovids (Criotherium, "Plesiaddax", Gangraia gen. nov.) predominate among larger taxa. Though taxonomic relations with other, roughly contemporaneous mammal fauna from neighbouring areas are evident (see Geraads, 2013), the overall bovid spectrum at Çorakyerler appears very particular and certainly worth further investigation.

Data availability. All specimens discussed within this paper are kept permanently in the listed museums. All data are described in the text, tables, and figures.

Author contributions. ASE, AYY, and SM collected and prepared the material. DSK, AYY, and SM illustrated the specimens. DSK described and analysed the material, designed and prepared the figures, and wrote the primary draft of the paper. ASE, AYY, and SM worked on the paper and contributed to the editing. All authors reviewed the final version of the paper and approved it.

Competing interests. The authors declare that they have no conflict of interest.

Acknowledgements. We are grateful to Denis Geraads and Faysal Bibi for critically commenting on a previous version of the article.

Financial support. Çorakyerler excavations are supported by the Turkish Ministry of Culture and Tourism, the General Directorate of Cultural Heritage and Museums, Ankara University, and the Turkish Historical Society.

Review statement. This paper was edited by Florian Witzmann and reviewed by Faysal Bibi and Zhaoqun Zhang. 


\section{References}

Alvarez, F.: Horns and fighting in male Spanish ibex, Capra pyrenaica, J. Mammal., 71, 608-616, 1990.

Begun, D. R., Güleç, E. S., and Geraads, D.: Dispersal patterns of Eurasian hominoids: implications from Turkey, Deinsea, 10, 2339, 2003.

Bibi, F.: A multi-calibrated mitochondrial phylogeny of extant Bovidae (Artiodactyla, Ruminantia) and the importance of the fossil record to systematics, BMC Evol. Biol., 13, 166, https://doi.org/10.1186/1471-2148-13-166, 2013.

Bibi, F. and Vrba, E.: Unraveling bovin phylogeny: accomplishments and challenges, BMC Biol., 8, 50, http://www. biomedcentral.com/1741-7007/8/50, 2010.

Bibi, F., Bukhsianidze, M., Gentry, A. W., Geraads, D., Kostopoulos, D. S., and Vrba, E. S.: The Fossil Record and Evolution of Bovidae: State of the Field, Palaeontol. Electron., 12, 1-11, 2009.

Bibi, F., Rowan, J., and Reed K.: Late Pliocene Bovidae from Ledi-Geraru (Lower Awash Valley, Ethiopia) and their implications for Afar paleoecology, J. Vertebr. Paleont., 37, e1337639, https://doi.org/10.1080/02724634.2017.1337639, 2017.

Bohlin, B.: Tsaidamotherium hedini, Geogr. Annaler, 17, 66-74, 1935.

Bohlin, B.: Eine tertiäre Saugetier-Fauna aus Tsaidam, Palaeontol. Sinica, 14, 1-111, 1937.

Bouvrain, G.: Un nouveau bovidé du Vallésien de Macèdoinie (Grèce), Acad. Sci. Paris, 280, 1357-1359, 1975.

Chen, G.-F. and Zhang, Z.-Q.: Restudy of Chinese bovids referred to Protoryx (Bovidae, Artiodactyla), Vert. PalAsiat., 45, 98-109, 2007.

Chen, L., Qiu, Q., Jiang, Y., Wang, K., Lin, Z., Li, Z., Bibi, F., Yang, Y., Wang, J., Nie, W., Su, W., Liu, G., Li, Q., Fu, W., Pan, W., Liu, C., Yang, J., Zhang, C., Yin, Y., Wang, Y., Zhao, Y., Zhang, C., Wang, Zh., Qin, Y., Liu, W., Wang, B., Ren, Y., Zhang, R., Zeng, Y., da Fonseca, R. R., Wei, B., Li, R., Wan, W., Zhao, R., Zhu, W., Wang, Y., Duan, S., Gao, Y, Zhang, Y. E., Chen, Ch., Hvilsom, Ch., Epps, C. W., Chemnick, L. G., Dong, Y., Mirarab, S., Siegismund, S. H., Ryder, O. A., Gilbert, M. T. P., Lewin H. A., Zhang, G., Heller, R., and Wang, W.: Large-scale ruminant genome sequencing provides insights into their evolution and distinct traits, Science, 364, 1152, https://doi.org/10.1126/science.aav6202, 2019.

Estes, R. D.: The significance of horns and other male secondary sexual characters in female bovids, Appl. Anim. Behav. Sci., 29, 403-451, 1974.

Gaudry, A.: Notes sur les antilopes trouvées à Pikermi (Grèce), B. Soc. Geol. Fr., 18, 388-400, 1861.

Gentry, A. W.: The earliest goats and other antelopes from Samos Hipparion Fauna, B. Brit. Mus. (Nat. Hist.), Geol., 20, 229-296, 1971.

Gentry, A. W.: Bovidae, in: Evolution of African mammals, edited by: Maglio, V. J. and Cooke, H. B. S., Harvard University Press, Cambridge, MA, USA, 540-572, 1979.

Gentry, A. W.: Evolution and dispersal of African Bovidae, in: Horns, Pronghorns, and Antlers, edited by: Bubenik, G. A. and Bubenik, A. B., Springer, New York, NY, USA, 195-233, 1990.

Gentry, A. W.: The subfamilies and tribes of the family Bovidae, Mammal Rev., 22, 1-32, 1992.
Gentry, A. W.: Caprinae and Hippotraginae (Bovidae, Mammalia) in the Upper Miocene, in: Antelopes, Deer, and Relatives, edited by: Vrba, E. and Schaller, G. B., Yale University Press, New Haven, CT, USA, 65-83, 2000.

Gentry, A. W.: Bovidae, in: Cenozoic mammals of Africa, edited by: Werdelin, L. and Sanders, W. J., University of California Press, Berkeley, CA, USA, 741-796, https://doi.org/10.1525/california/9780520257214.001.0001, 2010.

Geraads, D.: Large Mammals from the Late Miocene of Çorakyerler, Çankırı, Turkey, Acta Zool. Bulg., 65, 381-390, 2013.

Geraads, D.: A reassessment of the Bovidae (Mammalia) from the Nawata Formation of Lothagam, Kenya, and the late Miocene diversification of the family in Africa, J. Syst. Palaeontol., 17, 169182, https://doi.org/10.1080/14772019.2017.1403493, 2019.

Geraads, D. and Spassov, N.: A new species of Criotherium (Bovidae, Mammalia) from the late Miocene of Bulgaria, Hellenic J. Geosci., 43, 21-27, 2008.

Geraads, D., Blondel, C., Likius, A., Taisso Mackaye, H., Vignaud, P., and Brunet, P.: New Hippotragini (Bovidae, Mammalia) from the Late Miocene of Toros-Menalla (Chad), J. Vertebr. Paleontol., 28, 231-242, https://doi.org/10.1671/02724634(2008)28[231:NHBMFT]2.0.CO;2, 2008.

Gray, J. E.: On the natural arrangement of vertebrose animals, London Med. Repos., 15, 296-310, 1821.

Güleç, E. S., Sevim Erol, A., Pehlevan, C., and Kaya, F.: A new great ape from the late Miocene of Turkey, Anthropol. Sci., 115, 153-158, https://doi.org/10.1537/ase.070501, 2007.

Harris, J. M.: Bovidae from the Lothagam Succession, in: Lothagam: the dawn of humanity in Eastern Africa, edited by: Leakey, M. G. and Harris, J. M., Columbia University Press, New York, NY, USA, 530-558, https://doi.org/10.7312/leak11870022, 2003.

Hassanin, A., Delsuc, F., Ropiquet, A., Hammere, C., Jansen van Vuuren, B., Matthee, C., Ruiz-Garcia, M., Catzeflis, F., Areskoug, V., Thanh Nguyen, T., and Couloux, A.: Pattern and timing of diversification of Cetartiodactyla (Mammalia, Laurasiatheria), as revealed by a comprehensive analysis of mitochondrial genomes, C. R. Biol., 335, 32-50, https://doi.org/10.1016/j.crvi.2011.11.002, 2012.

Kaya, F., Kaymakçi, N., Bibi, F., Eronen, J. T., Pehlevan, C., Erkman, A. C., Langereis, C. G., and Fortelius, M.: Magnetostratigraphy and paleoecology of the hominidbearing locality Çorakyerler, Tuğlu Formation (Çankırı Basin, Central Anatolia), J. Vertebr. Paleontol., 36, e1071710, https://doi.org/10.1080/02724634.2015.1071710, 2016.

Kaymakçi, N., Özelik, Y., White, S. H., and van Dijk, P. M.: Neogene tectonics of the Çankırı Basin (north Central Turkey), Türkiye Petrol Jeol. Dernegi Bül., 13, 27-56, 2001.

Khomenko, J.: La faune méotique du village Taraklia du district de Bendery, Annuaire Geol. Mineral. Russie, 15, 107-143, 1913.

Kingdon, J.: East African Mammals: an Atlas of Evolution in Africa, The University Chicago Press, Chicago, IL, USA, 1982.

Köhler, M.: Boviden des türkischen Miozäns (Känozoikum und Braunkholen der Türkei, Paleontol. Evol., 21, 133-246, 1987.

Kostopoulos, D. S.: Bovidae, The late Miocene Mammal faunas of the Mytilinii basin, Samos Island, Greece: new collection, Beitr. Paläont., 31, 305-349, 2009. 
Kostopoulos, D. S.: Taxonomic reassessment and phylogenetic relationships of Miocene homonymously spiralhorned antelopes, Acta Palaeontol. Pol., 59, 9-29, https://doi.org/10.4202/app.2011.0013, 2014.

Kostopoulos, D. S., Sevim Erol, A., Mayda, S., Yavuz, Y. A., and Tarhan, E.: Qurliqnoria (Bovidae, Mammalia) from the Upper Miocene of Çorakyerler (Central Anatolia, Turkey) and its biogeographic implications, Palaeoworld, 29, 629-635, https://doi.org/10.1016/j.palwor.2019.10.003, 2020.

Kretzoi, M.: New generic names for homonyms, Vertebrat. Hungarica, 10, 163-166, 1968.

Liu, D. S., Li, G. K., and Zhai, R. J.: Pliocene vertebrates of Lantian, Shansi, Prof. Papers Stratigr. Paleontol., 7, 149-200, 1978 (in Chinese).

Lundrigan, B.: Morphology of horns and fighting behavior in the family Bovidae, J. Mammal., 77, 462-475, 1996.

Major, C. I. F.: Considerations nouvelles sur la faune des vertébrés du Miocène supérieur dans l'Île de Samos, C. R. Hebd. Séanc. Acad. Sci. Paris, 113, 608-610, 1891.

Owen, R.: Description of teeth and portions of jaws of two extinct anthracotheroid quadrupeds (Hydropotamus vectianus and Hyop. bovinus) discovered by the Marchioness of Hastings in the Eocene deposits of the N. W. coast of the Isle of Wight: with an attempt to develop Cuvier's idea of the classification of pachyderms by the number of their toes, Q. J. Geol. Soc. London, 4, 103-141, 1848.

Pilgrim, G. E.: The fossil Bovidae of India, Palaeontol. Indica, 26, 1-356, 1939.

Qiu, Z.-X., Wang, B.-Y., and Xie, G.-P.: Preliminary report on a new genus of Ovibovinae from Hezheng district, Gansu, China, Vert. PalAsiat., 38, 128-134, 2000.

Rodler, A.: Notiz über ein im Besitze des Dr. J. E. Polak befindliches Schädelfragment eines Sivatheriden vom Knochenfelde von Maragha am Urmiasee in Nordpersien, Anz. Österreich. Akad. Wissensch. Math. Nat. K1., 25, 114-115, 1888.

Schlosser, M.: Die fossilen Säugetiere Chinas nebst einer Odontographie der recenten Antilopen, Abh. Bayer. Akad. Wissensch. Math. Nat. K1., 22, 1-221, 1903.

Schlosser, M.: Die fossilen Cavicornier von Samos, Beitr. Paläont. Geol. Öster.-Ungarns, 17, 21-118, 1904.

Sevim Erol, A., Begun, D. R., Güleç, E., Geraads, D., and Pehlevan, C.: A new late Miocene hominid from Turkey, Am. J. Phys. Anthropol., 32, 134-135, 2001.
Sevim Erol, A., Yavuz, Y. A., Tarhan, E., Mayda, S., Aytek, A. I., Sönmez Sözer, Ç., Mutlu, H., Alçiçek, H., and Alçiçek, C.: Çorakyerler kazisi 2018 yili çalişmalari [Çorakyerler excavation studies in 2018], in: Proceedings of the 41th International Symposium of Excavations, Surveys and Archaeometry, 1721 June 2020, Diyarbakir, Turkey, 285-297, 2020 (in Turkish).

Shi, Q. Q.: New species of Tsaidamotherium (Bovidae, Artiodactyla) from China sheds new light on the skull morphology and systematics of the genus, Sci. China Earth Sci., 57, 258-266, https://doi.org/10.1007/s11430-013-4722-2, 2014.

Shi, Q. Q., Xe, W., and Chen, S.: A new species of Shaanxispira (Bovidae, Artiodactyla) from the upper Miocene of China, Zootaxa, 3794, 501-513, https://doi.org/10.11646/zootaxa.3794.4.1, 2014.

Shi, Q. Q., Wang, S.-Q., Chen, S.-K., and Li, Y.-K.: The first discovery of Urmiatherium (Bovidae, Artiodactyla) from Liushu Formation, Linxia Basin. Vert. PalAsiat., 10, 319-331, 2016.

Sickenberg, O.: Die Gliederung des höheren Jungtertiärs und Altquartärs in der Türkei nach Vertebraten und ihre Bedeutung für die internationale Neogen-Stratigraphie, Geologisches Jahrbuch, 15, 1-167, 1975.

Ünay, E., de Bruijn, H., and Suata-Alpaslan, F.: Rodents from the Upper Miocene Hominoid locality Çorakyerler (Anatolia), Beitr. Paläont., 30, 463-467, 2006.

Vrba, E. S.: Phylogenetic analysis and classification of fossil and recent Alcelaphini Mammalia: Bovidae, Biol. J. Linn. Soc., 11, 207-228, 1979.

Vrba, E. S.: New fossils of Alcelaphini and Caprinae (Bovidae: Mammalia) from Awash, Ethiopia, and phylogenetic analysis of Alcelaphini, Palaeontol. Africana, 34, 127-198, 1997.

Vrba, E. S., Vaisnys, J. R., Gatesy, J. E., DeSalle, R., and Wei, K-Y.: Analysis of paedomorphosis using allometric characters: the example of Reduncini antelopes (Bovidae, Mammalia), Systematic Biol., 43, 92-116, 1994.

Wang, S.-Q., Yang, Q., Zhao, Y., Li, C.-X., Shi, Q.-Q. Zong, L.-Y., and Ye, J.: New Olonbulukia material and its related assemblage reveal an early radiation of stem Caprini along the north of the Tibetan Plateau, J. Paleontol., 93, 385-397, https://doi.org/10.1017/jpa.2018.65, 2018. 